\title{
Clean and Green Synthesis of New Benzothiazole Derivatives via Electrochemical Oxidation of Catechol Derivatives
}

\author{
Mansour Arab Chamjangali, ${ }^{*}$ Hassan Daneshinejad, Mohammad Bakherad, Mohsen Ameri
}

\author{
College of Chemistry, Shahrood University of Technology, Shahrood, P.O. Box 36155-316, Iran \\ * Corresponding author's e-mail address: marab@shahroodut.ac.ir
}

RECEIVED: March 15, 2015 * REVISED: July 15, 2015 * ACCEPTED: September 15, 2015

Abstract: Electrochemical oxidation of the catechols $1 \mathrm{a}$ and $\mathbf{1 b}$ is studied in the presence of 6-methyl-2-thouracil (3b) and 6-propyl-2-thiouracil (3a) as nucleophiles in a phosphate buffer $\left(0.15 \mathrm{~mol} \mathrm{~L}^{-1}, \mathrm{pH}=6.8\right) / \mathrm{DMF}(95: 5)$ solution using cyclic voltammetry and controlled-potential coulometry. The results obtained indicate that the quinones derived from the catechols participate in 1,4-Michael-addition reactions with the nucleophiles to form the corresponding new benzothiazole compounds. In this work, we derive a variety of products with good yields using controlled potential at graphite electrodes in an undivided cell.

Keywords: catechol, thiouracil, 1,4-Michael addition, controlled potential.

\section{INTRODUCTION}

C ATECHOLS and their derivatives play important roles in medical and biological systems since many important biological molecules such as adrenalin and dopamine have catechol in their structures. ${ }^{[1]}$ Thus in vitro synthesis of the material produced by catechol by means of green chemistry can be significantly helpful in pharmaceutical industry, which can be achieved by good electrochemical behavior of catechol and its oxidation in this way. Electrochemical oxidation of $o$ - and $p$-diphenols has been studied by several researchers. ${ }^{[2,3]} O$ - and $p$-quinines produced by oxidation of $o$ - and $p$-catechols are unstable compounds, and can be used as an acceptor in the Micheleaddition reaction, which undergo attacks by nucleophiles such as 5-methyl-2-mercapto-1,3,4-thiadiazole, ${ }^{[4]}$ 1,3-diethyl-2-thiobarbituric acid, ${ }^{[5]}$ Meldrum's acid, ${ }^{[6]}$ cyanoacetone, ${ }^{[7]}$ and 3-hydroxy- $1 \mathrm{H}$-phenalene-1-one. ${ }^{[8]}$

Thiouracils are minor components of transfer-RNA, have anti-herpes virus activities, and have been used for the treatment of hyperthyroidism in men. ${ }^{[9-13]}$ With respect to the properties of these compounds, synthesis of derivatives of thiouracils by means of green chemistry becomes important. These compounds are usually used as anti-bacterial in human. In this work, the electrochemical synthesis of benzothiazole derivatives in aqueous media was investigated. The product with high purity and good selectivity was obtained with high yield. FT-IR, ${ }^{1} \mathrm{H}$ - and ${ }^{13} \mathrm{C}$ - NMR, melting point (mp), and elemental analysis ( $\mathrm{CHN}$ ) were used to characterize the new synthesized products.

\section{EXPERIMENTAL}

\section{Materials and Instrumentations}

All of the chemical reagents and phosphate salts were of proanalysis grade, purchased from Merck Company, and were used without further purification. Cyclic voltammetric experiments were performed using a Metrohm voltammetric analyzer Model 757. Controlled-potential coulometry was performed using a Behpajooh Model 2063 potentiostat/galvanostat. The working electrode (WE) used in the voltammetry experiments was a glassy carbon disk ( $2 \mathrm{~mm}$ diameter), and a platinum disc was used as the auxiliary electrode ( $A E$ ). The WE potentials were measured versus the $3 \mathrm{~mol}$ $\mathrm{L}^{-1}$ of $\mathrm{KCl} \mathrm{Ag} / \mathrm{AgCl}$ reference electrode. (All electrodes were 
obtained from AZAR electrode.) The WE used in controlledpotential coulometry was an assembly of three carbon rods $(6$ $\mathrm{mm}$ diameter and $8 \mathrm{~cm}$ length), and a sheet of platinum $\left(1 \mathrm{~cm}^{2}\right)$ constituted the AE. NMR spectra were recorded on Bruker-80 and Bruker-400 advance instruments. IR spectra were recorded on a Shimadzu 8400 S FT-IR spectrophotometer.

\section{General Procedure for Electrochemical Synthesis (6a-6d)}

In a typical procedure, $100 \mathrm{~mL}$ of a DMF-water mixture $(5: 95 \mathrm{v} / \mathrm{v})$ containing phosphate buffer $\left(0.15 \mathrm{~mol} \mathrm{~L}^{-1}, \mathrm{pH}=\right.$ 6.8) was pre-electrolyzed at $0.40 \mathrm{~V} v$ s. $\mathrm{Ag} / \mathrm{AgCl}$ (the applied potential during the electrolysis was $0.4 \mathrm{~V}$ ) in an undivided cell for $15 \mathrm{~min}$. Then $5.0 \times 10^{-4} \mathrm{~mol}$ of catechol $(\mathbf{1 a}-\mathbf{1 b})$ and $5.0 \times 10^{-4} \mathrm{~mol}$ of thiouracil derivatives (3a or $\mathbf{3 b}$ ) were added to the cell, and the electrolysis was continued until the current decreased by more than $95 \%$ of the beginning current value. The process was interrupted for seven times during the electrolysis, and the graphite anode was washed in acetone in order to reactivate it. During the electrolysis, precipitation of the product happens and the reaction mixture is become cloudy. At the end of the electrolysis, the cell was left in refrigerator overnight at $4.0^{\circ} \mathrm{C}$ for complete precipitation. The precipitated solid was collected by filtration, and crystallized from a mixture of methanol-acetone $(60: 40 \mathrm{v} / \mathrm{v})$. After crystallization, the products were characterized by FT-IR, ${ }^{1} \mathrm{H}-\mathrm{NMR},{ }^{13} \mathrm{C}-\mathrm{NMR}, \mathrm{mp}$, and $\mathrm{CHN}$.

\section{4-Propyl-2H-pyrimido [2,1-d][1,3]benzothiazole-7,8-diol} (6a)

Light brown solid, (75 \%); m.p. > $300{ }^{\circ} \mathrm{C}$; FT-IR (KBr) $\tilde{v}_{\max }$ $/ \mathrm{cm}^{-1}$ : $3250(\mathrm{OH}), 1650$ (C=O); ${ }^{1} \mathrm{H}-\mathrm{NMR}$ (DMSO-d $\left.d_{6}\right) \delta / \mathrm{ppm}$ : 0.89-1.69 (m, 7H, Pr), $6.18(\mathrm{~s}, 1 \mathrm{H}, \mathrm{CH}), 7.12(\mathrm{~s}, 1 \mathrm{H}, \mathrm{ArH})$, 7.33 (s, 1H, ArH), 9.07 (s, 1H, OH), $10.22(\mathrm{~s}, 1 \mathrm{H}, \mathrm{OH}) ;{ }^{13} \mathrm{C}-$

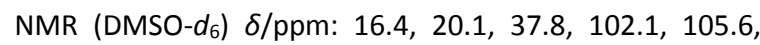
114.1, 117.8, 127.2, 143.9, 145.2, 160.2, 162.5, 164.4 .

Anal. Calcd. mass fractions of elements, $w / \%$, for $\mathrm{C}_{13} \mathrm{H}_{12} \mathrm{~N}_{2} \mathrm{O}_{3} \mathrm{~S}(\mathrm{M}=276.31)$ are: $\mathrm{C} 56.51, \mathrm{H} 4.38, \mathrm{~N} 10.14$. Found: C 56.44, H 4.42, N 10.08 .

\section{6-Methyl-4-propyl-2H-pyrimido [2, 1-d][1,3]benzothia- zole-7,8-diol (6b)}

Light brown solid, (68\%); m.p. > $300{ }^{\circ} \mathrm{C}$; FT-IR $(\mathrm{KBr}) \tilde{v}_{\max }$ $/ \mathrm{cm}^{-1}: 3240(\mathrm{OH}), 1666$ (C=O); ${ }^{1} \mathrm{H}-\mathrm{NMR}$ (DMSO-d $\left.d_{6}\right) \delta / \mathrm{ppm}$ : 0.90-1.68 (m, 7H, Pr), $2.25\left(\mathrm{~s}, 3 \mathrm{H}, \mathrm{CH}_{3}\right), 6.10(\mathrm{~s}, 1 \mathrm{H}, \mathrm{CH})$, $7.18(\mathrm{~s}, 1 \mathrm{H}, \mathrm{ArH}), 8.87(\mathrm{~s}, 1 \mathrm{H}, \mathrm{OH}), 10.12(\mathrm{~s}, 1 \mathrm{H}, \mathrm{OH}) ;{ }^{13} \mathrm{C}-$ NMR (DMSO- $\left.d_{6}\right) \delta / p p m: 13.4,18.5,20.8,38.2,105.2$, 106.3, 108.3, 113.2, 128, 144.9, 145.6, 160, 162, 165.2 .

Anal. Calcd. mass fractions of elements, $w / \%$, for $\mathrm{C}_{14} \mathrm{H}_{14} \mathrm{~N}_{2} \mathrm{O}_{3} \mathrm{~S}:(\mathrm{M}=290.34)$ are: $\mathrm{C} 57.92, \mathrm{H} 4.86, \mathrm{~N} 9.65$. Found: C 57.88, H 4.91, N 9.70.
4-Methyl-2H-pyrimido [2,1-d][1,3]benzothiazole-7,8-diol (6c):

White solid, (70\%); m.p. > $300{ }^{\circ} \mathrm{C}$; IR (KBr) $\tilde{v}_{\max } / \mathrm{cm}^{-1}: 3170$

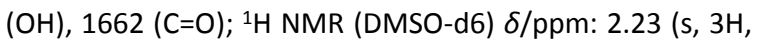
$\left.\mathrm{CH}_{3}\right), 6.25(\mathrm{~s}, 1 \mathrm{H}, \mathrm{CH}), 7.25-7.65(2 \mathrm{H}, \mathrm{ArH}), 9.65(\mathrm{br}, 2 \mathrm{H}$, $\mathrm{OH})$.

Anal. Calcd. mass fractions of elements, $w / \%$, for $\mathrm{C}_{11} \mathrm{H}_{8} \mathrm{~N}_{2} \mathrm{O}_{3} \mathrm{~S}:(\mathrm{M}=248.26)$ are: $\mathrm{C} 53.22, \mathrm{H} 3.25, \mathrm{~N} 11.28$. Found: C 53.16, H 3.28, N 11.34.

\section{4,6-Dimethyl-2H-pyrimido [2,1-d][1,3]benzothiazole-7,8- diol (6d):}

White solid, (64\%); m.p. > $300{ }^{\circ} \mathrm{C}$; IR (KBr) $\tilde{v}_{\max } / \mathrm{cm}^{-1}: 3140$ (OH), 1654 (C=O); ${ }^{1} \mathrm{H}-\mathrm{NMR}$ (DMSO-d6) $\delta / p p m: 2.25$ (s, 3H, $\left.\mathrm{CH}_{3}\right), 2.65\left(\mathrm{~s}, 3 \mathrm{H}, \mathrm{CH}_{3}-\mathrm{ArH}\right), 6.25$ (s, $\left.1 \mathrm{H}, \mathrm{CH}\right), 7.46-7.55$ (s, $1 \mathrm{H}, \mathrm{ArH}), 8.65(\mathrm{br}, 2 \mathrm{H}, \mathrm{OH})$.

Anal. Calcd. mass fractions of elements, $w / \%$, for $\mathrm{C}_{12} \mathrm{H}_{10} \mathrm{~N}_{2} \mathrm{O}_{3} \mathrm{~S}$ : $(\mathrm{M}=262.28)$ are: $\mathrm{C} 54.95, \mathrm{H} 3.84, \mathrm{~N} 10.68$. Found: C 54.98, H 3.80, N 10.73.

\section{RESULTS AND DISCUSSION}

\section{Cyclic Voltammetric Studies}

Cyclic voltammetry of $2.0 \times 10^{-3} \mathrm{~mol} \mathrm{~L}^{-1}$ of catechol (1a) in DMF-water mixture $(5: 95 \mathrm{v} / \mathrm{v})$ containing phosphate buffer ( $0.15 \mathrm{~mol} \mathrm{~L}^{-1}, \mathrm{pH}=6.8$ ) as the supporting electrolyte shows one anodic $\left(A_{1}\right)$ and a corresponding cathodic peak $\left(C_{1}\right)$, which belongs to the transformation of catechol (1a) to $o$ benzoquinone (4a) and vice versa within a quasi-reversible two-electron process (Figure 1, curve a). A peak current ratio $\left(l_{\mathrm{p}}^{\mathrm{C} 1} / I_{\mathrm{p}}^{\mathrm{A} 1}\right)$ of nearly unity, particularly during the recycling of the potential, can be considered as a criterion for the stability of $o$-benzoquinone produced at the surface of the electrode under the experimental conditions. In other words, any hydroxylation or dimerization reactions are too slow to be observed on the time scale of the cyclic voltammetry. ${ }^{14}$ Oxidation of the catechol (1a) in the presence of $\mathbf{3 a}$ and $\mathbf{3 b}$ as nucleophiles was studied in some detail. Figure 1 (curves $b$ and $c$ ) shows the cyclic voltammograms obtained for a $2.0 \times 10^{-3} \mathrm{~mol} \mathrm{~L}^{-1}$ solution of $1 \mathrm{a}$ in the presence of $2.0 \times 10^{-3} \mathrm{~mol} \mathrm{~L}^{-1}$ of $\mathbf{3} \mathbf{a}$ and $\mathbf{3} \mathbf{b}$ under the experimental conditions. The voltammograms exhibits one anodic peak at $0.25 \mathrm{~V}$ versus $\mathrm{Ag} / \mathrm{AgCl}$, and the cathodic counterpart of the anodic peaks $\mathrm{A} 1$ almost disappears. The anodic peak (A1) shifts to positive potentials and the cathodic peak (C1) shifts to negative potentials, in the presence of $\mathbf{3 a}$ and $\mathbf{3 b}$ (Figure 1, curves $b$ and $c$ ), are probably because of the formation of a thin film of product at the surface of the electrode, inhibiting, to a certain extent, the performance of the electrode process. ${ }^{15}$ The voltammograms of $\mathbf{3} \mathbf{a}$ and $\mathbf{3 b}$ 


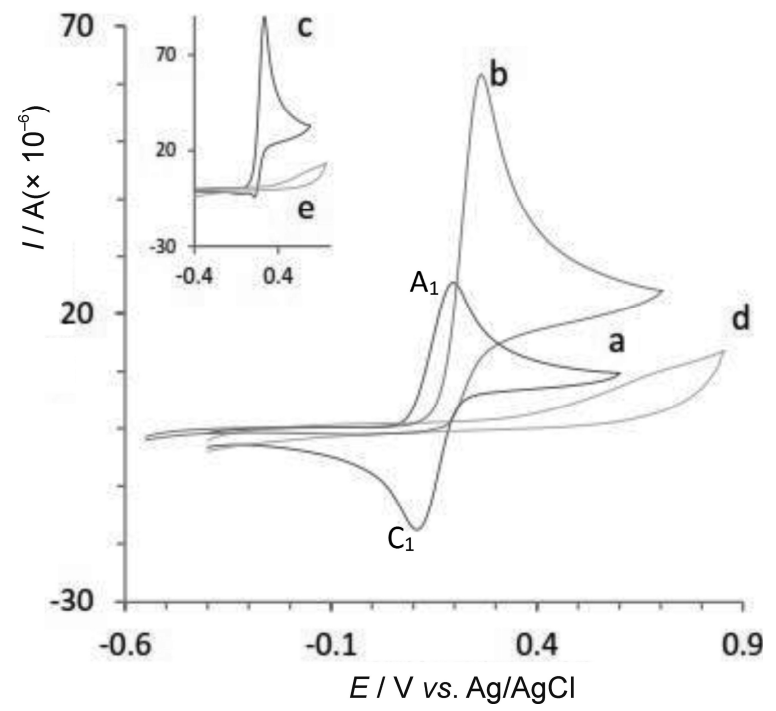

Figure 1. Cyclic voltammograms of $2.0 \times 10^{-3} \mathrm{~mol} \mathrm{~L}^{-1}$ of $1 \mathrm{a}$ (a) in the absence, (b) in the presence of $2.0 \times 10^{-3} \mathrm{~mol} \mathrm{~L}^{-1}$ of $3 a$, (c) in the presence of $3 b$. Cyclic voltammograms of 2.0 $\times 10^{-3} \mathrm{~mol} \mathrm{~L}^{-1}$ of $3 \mathrm{a}$ and $3 \mathrm{~b}$ in the absence of catechol $(\mathrm{d})$ and (e), respectively; scan rate of $50 \mathrm{mV} \mathrm{s}^{-1}$, at a glassy carbon electrode, under experimental conditions, and $T=$ $25^{\circ} \mathrm{C}$.

in the absence of $\mathbf{1 a}$ are shown in Figure 1, curves $\mathbf{d}$ and $\mathbf{e}$. These compounds are electrochemically inactive in the range of the potential studied. In addition the cyclic voltammogram of isolated and purified product 6a was recorded under the same conditions but in DMF media (not soluble in water/DMF mixture). The resultant cyclic voltammogram (not shown here) shows that the product $\mathbf{6 a}$ is elecroactive with an anodic peak around $0.3 \mathrm{~V}$ ( $v s$. $\mathrm{Ag} / \mathrm{AgCl})$, which is very close to starting material $1 \mathrm{a}$. It is important to note that the final products are insoluble in water and precipitate during the electrolysis. Thus a few amounts of adsorbed products could be oxidized under the applied potential range during the electrolysis.

The multi-cyclic voltammograms of $1 \mathbf{a}$ in the presence of $\mathbf{3} \mathbf{a}$ and $\mathbf{3} \mathbf{b}$ were also recorded (Figure 2). It is clear that no additional anodic peak related to the oxidation of $\mathbf{4 a}$ and $\mathbf{4 c}$ is observed in the consecutive cycles. This is probably due to this fact that the oxidation of potentials $4 a$ and $\mathbf{4 c}$ are very close to the oxidation potential of the starting material 1a. In addition, no observable and separate anodic peak due to oxidation of the reaction products ( $\mathbf{6 a}$ and $\mathbf{6 c}$ ) is detected. Although the products are electroactive at the studied potential range, but due to their insolubility and thus precipitation in the reaction media, only a few amounts of products is adsorbed on the electrode surface and thus could be oxidized with an oxidation peak close to starting material $\mathbf{1 a}$ and $\mathbf{1 b}$ and intermediates $\mathbf{4 a}$ and $\mathbf{4 b}$.
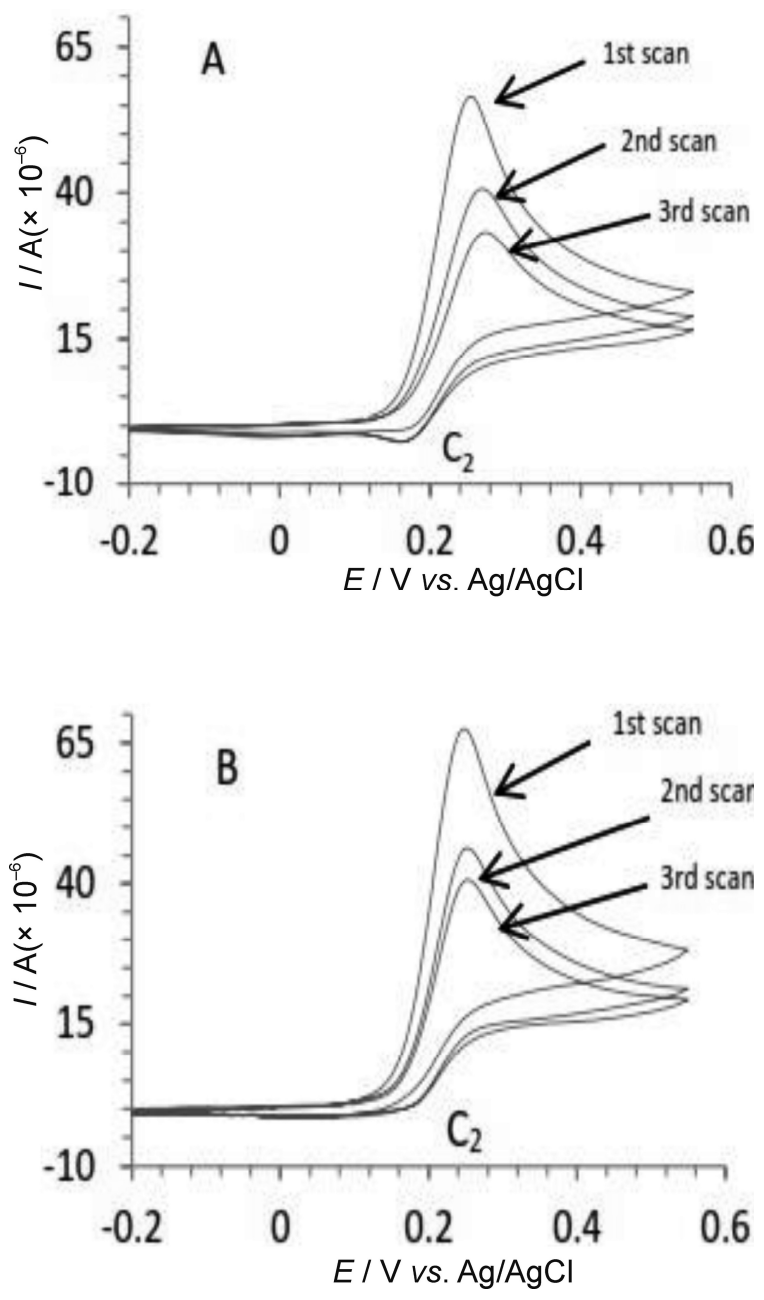

Figure 2. Multi-cyclic voltammograms of $2.0 \times 10^{-3} \mathrm{~mol} \mathrm{~L}^{-1}$ of $1 \mathrm{a}$ in the presence of $2.0 \times 10^{-3} \mathrm{~mol} \mathrm{~L}^{-1}$ of $3 \mathrm{a}(\mathrm{A})$ and $3 \mathrm{~b}$ (B) under experimental conditions at glassy carbon electrode (2 mm diameter); scan rate of $100 \mathrm{mV} \mathrm{s}^{-1}$; room temperature.

The weak cathodic peak at $C_{2}$ is due to reduction of the oxidized form of product and/or intermediate $\mathbf{5}$, which have partially been adsorbed on the surface of electrode.

The electrochemical behaviors of $1 \mathbf{a}$ in the presence of $\mathbf{3 a}$ and $\mathbf{3} \mathbf{b}$ were also investigated at different scan rates (Figures 3 and 4). The current function for the anodic peak $I_{\mathrm{p}}^{\mathrm{A} 1} / V^{1 / 2}$ decreases slightly with increasing scan rate (Figure 5 , curves $A$ and $B$ ). Such a behavior is adopted as indicative of an ECEC mechanism. ${ }^{16}$ At high scan rates and in the presence of $\mathbf{3 b}$, cathodic peak of catechol appeared, while in the presence of other nucleophile, 3a, this behavior was not observed even at higher scan rates. These results can be attributed to less reactivity of $\mathbf{3} \mathbf{b}$ compared to $\mathbf{3} \mathbf{a}$. The lower reaction yield of $\mathbf{3 b}$ (70 \%) compared to yield of $\mathbf{3 a}$ (75\%) confirms the less reactivity of $\mathbf{3 b}$. 


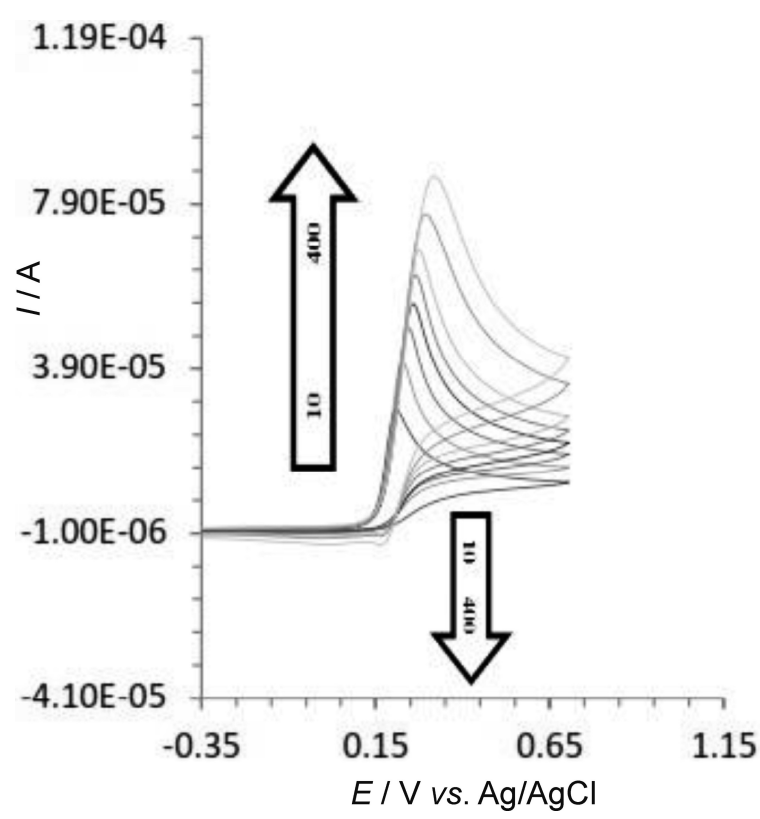

Figure 3. Typical voltammograms of $2.0 \times 10^{-3} \mathrm{~mol} \mathrm{~L}^{-1}$ of $1 \mathrm{a}$ in the presence of $2.0 \times 10^{-3} \mathrm{~mol} \mathrm{~L}^{-1}$ of $3 \mathrm{a}$ under experimental conditions at glassy carbon electrode $(2 \mathrm{~mm}$ diameter) at various scan rates: $10,25,50,80,100,150$, 200 , and $400 \mathrm{mV} \mathrm{s}^{-1}$

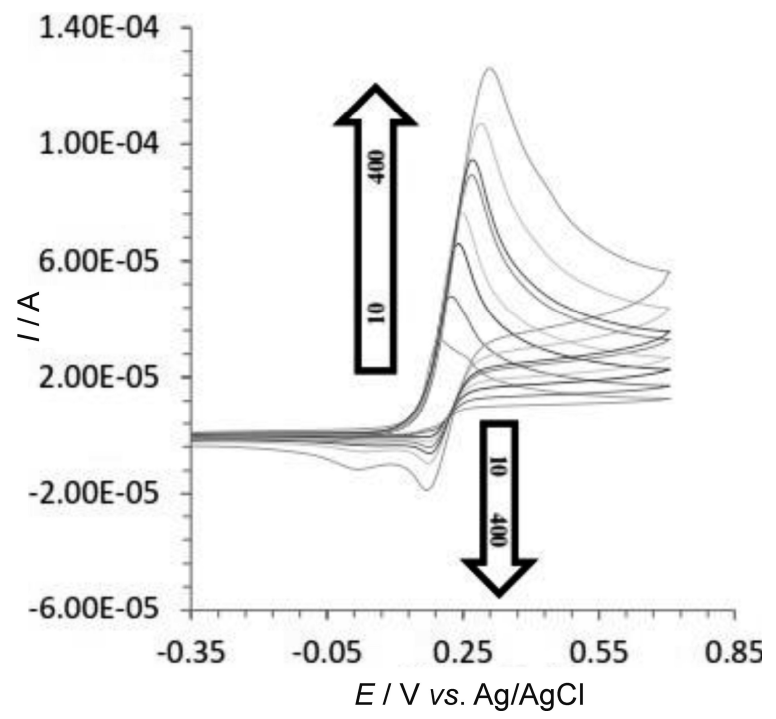

Figure 4. Typical voltammograms of $2.0 \times 10^{-3} \mathrm{~mol} \mathrm{~L}^{-1}$ of $1 \mathrm{a}$ in the presence of $2.0 \times 10^{-3} \mathrm{~mol} \mathrm{~L}^{-1}$ of $3 \mathrm{~b}$ under experimental conditions at glassy carbon electrode $(2 \mathrm{~mm}$ diameter) at various scan rates: $10,25,50,80,100,150$, 200 , and $400 \mathrm{mV} \mathrm{s}^{-1}$.
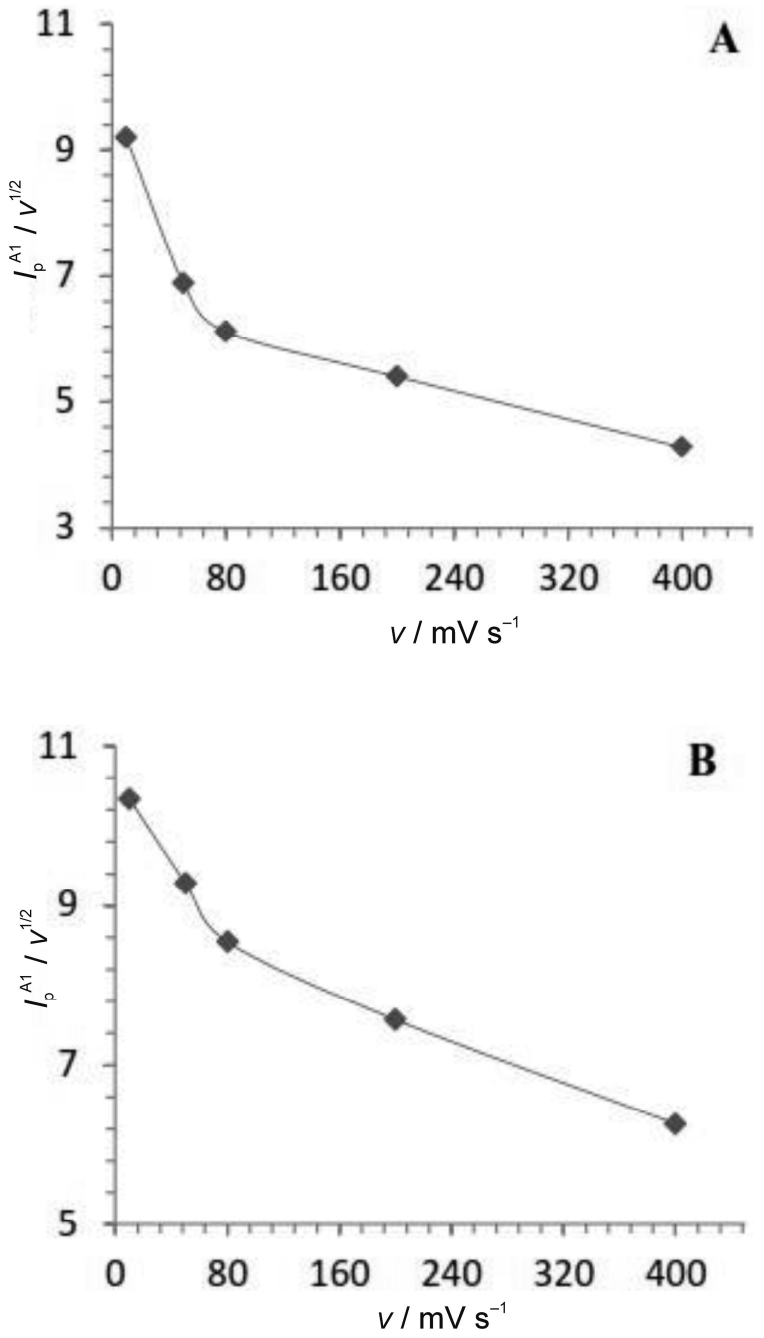

Figure 5. Variation of $\left(I_{p} \mathrm{~A}^{1} / V^{1 / 2}\right)$ versus scan rate for $2.0 \times 10^{-3}$ $\mathrm{mol} \mathrm{L^{-1 }}$ of $1 \mathrm{a}$ in the presence of $2.0 \times 10^{-3} \mathrm{~mol} \mathrm{~L}^{-1}$ of $3 \mathrm{a}(\mathrm{A})$, and in the presence of $2.0 \times 10^{-3} \mathrm{~mol} \mathrm{~L}^{-1}$ of $3 \mathrm{~b}(\mathrm{~B})$, under experimental conditions; scan rates are $10,50,80,200$, and $400 \mathrm{mV} \mathrm{s}^{-1}$; room temperature.

\section{Investigation of Electrochemical Synthesis Conditions}

In the electrochemical synthesis, the electrochemical results could be significantly affected by different instrumental parameters such as electrode materials, kind of cell (divided cell or undivided cell), mode of electrolysis (controlled potential or constant current), and chemical parameters including $\mathrm{pH}$ and nature and concentration of the supporting electrolytes. Some literature studies show that in the electrochemical synthesis involving catechol derivatives as substrate, use of carbon electrodes and applying controlled potential electrolysis in an undivided cell are preferred. ${ }^{[17,18]}$ Therefore, these instrumental conditions were first selected in the optimization of other parameters 

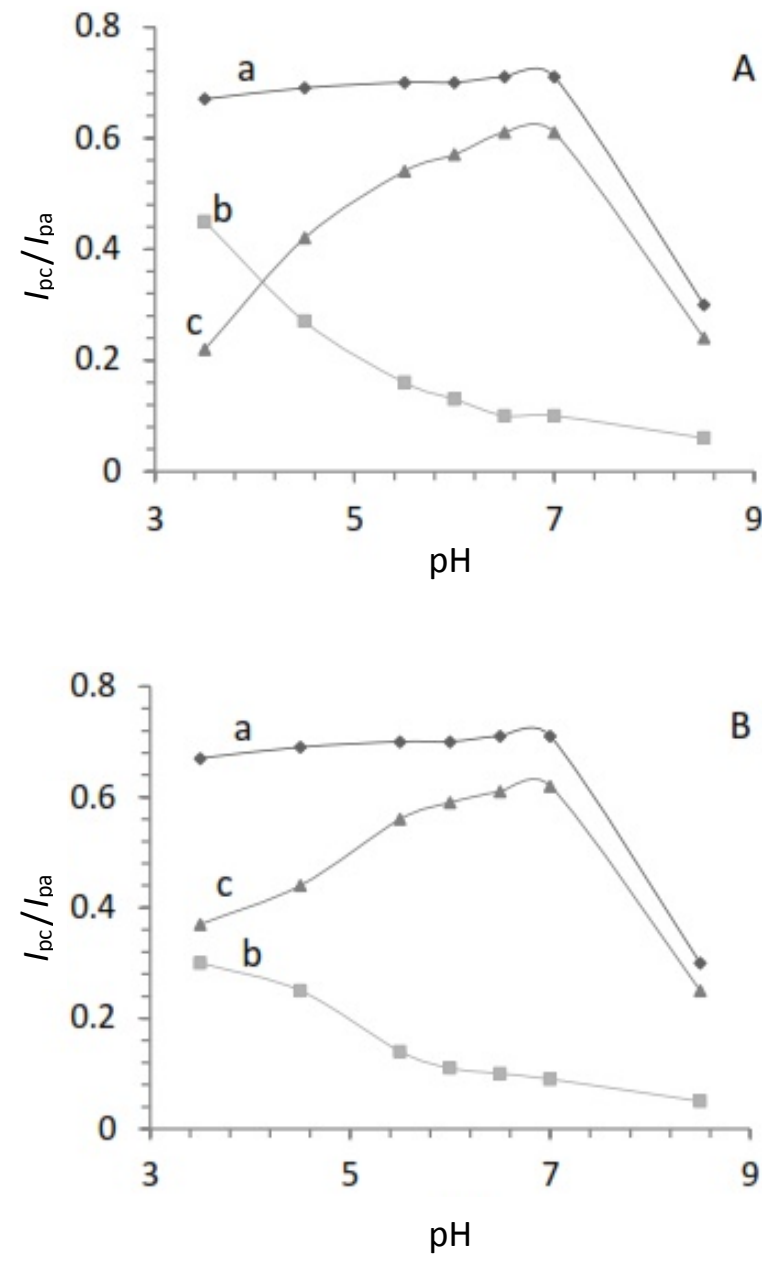

Figure 6. Variation of peak current ratio $\left(/ \mathrm{p}^{\mathrm{C}} / \mathrm{p}_{\mathrm{p}}^{\mathrm{A}}\right)$ with $\mathrm{pH}$. A) $2.0 \times 10^{-3} \mathrm{~mol} \mathrm{~L}^{-1}$ of $1 \mathrm{a}$ in the absence of $3 \mathrm{a}(\mathrm{a}), 2.0 \times 10^{-3}$ mol $L^{-1}$ of $1 a$ in the presence of $3 a(b)$, and difference between curves $a$ and $b$ (c). B) $2.0 \times 10^{-3} \mathrm{~mol} \mathrm{~L}^{-1}$ of $1 \mathrm{a}$ in the absence of $3 b(a), 2.0 \times 10^{-3} \mathrm{~mol} \mathrm{~L}^{-1}$ of $1 \mathrm{a}$ in the presence of $3 b(b)$, and difference between curves $a$ and $b(c)$.

such as $\mathrm{pH}$ and concentration of the supporting electrolyte. In all studies, catechol (1a) was chosen as a model compound to investigate the appropriate conditions, and then the optimized conditions were applied to the other catechol (1b).

Effect of $\mathrm{pH}$ of the electrolytic solution was studied in the range of 3.5-8.5. For this purpose, the cyclic voltammograms of $2.0 \times 10^{-3} \mathrm{~mol} \mathrm{~L}^{-1}$ of catechol (1a) were recorded in the absence and presence of $\mathbf{3} \mathbf{a}$ and $\mathbf{3} \mathbf{b}$ at different
Table 1. Yield of product $6 \mathrm{a}$ and $6 \mathrm{c}$ at different supporting electrolyte concentration

\begin{tabular}{lcccc}
\hline \multicolumn{2}{l}{ Applied potential / V } & 0.10 & 0.15 & 0.20 \\
\hline Yield (\%) & $6 a$ & 74 & 75 & 75 \\
Yield (\%) & $6 \mathrm{c}$ & 70 & 70 & 69 \\
\hline
\end{tabular}

$\mathrm{pH}$ values (the results obtained have not been shown here). Voltammetric behavior of catechols at various $\mathrm{pH}$ values is well-known and has been investigated earlier [7]. In acidic and neutral media, the peak-current ratio $\left(/_{\mathrm{P}} \mathrm{C} 1 / I_{\mathrm{P}} \mathrm{P}^{\mathrm{A}}\right)$ is near unity, while in basic solution, th e peak-current ratio $\left(I_{\mathrm{P}} \mathrm{C} 1 / I_{\mathrm{P}}{ }^{\mathrm{A} 1}\right)$ is less than unity and decreases with increase in the $\mathrm{pH}$ (Figure 6, curve a). This is related to the dimerization reactions. ${ }^{19-21}$ The results obtained from oxidation of catechol (1a) in the presence of $\mathbf{3} \mathbf{a}$ and $\mathbf{3} \mathbf{b}$ at different $\mathrm{pH}$ values show that the peak-current ratio $\left(/_{\mathrm{P}} \mathrm{C} 1 / \mathrm{I}_{\mathrm{P}}^{\mathrm{A} 1}\right)$ decreases with increase in the $\mathrm{pH}$ (Figure 6, curve b). The difference between peak-current ratio in the presence and absence of 3a and $\mathbf{3 b}$ were also shown in Figure 6, curve c. Essentially, due to reducing the rate of the polymerization reaction of catechol and increasing the rate of coupling reaction between $\mathbf{3 a}$ and $\mathbf{3 b}$ with $\boldsymbol{o}$-benzoquinone, a solution of DMFwater mixture $(5: 95)$ containing phosphate buffer ( $\mathrm{pH} 6.8)$ was selected as the most suitable supporting electrolyte for synthesis.

Effect of the supporting electrolyte concentration on the yield of products $6 a$ and $6 c$ was studied using $0.10,0.15$, and $0.20 \mathrm{~mol} \mathrm{~L}^{-1}$ of phosphate buffer $(\mathrm{pH}=6.8)$. The results obtained demonstrate that the yields of $\mathbf{6 a}$ and $\mathbf{6 c}$ are nearly constant, and are independent from the electrolyte concentration (Table 1). Thus a $0.15 \mathrm{~mol} \mathrm{~L}^{-1}$ phosphate buffer solution ( $\mathrm{pH}$ 6.8) was used as the reaction medium.

Generally, the yield is also dependent on the applied potential in the controlled-potential electrolysis. Therefore, the effect of applied potential on the yield of $\mathbf{6 a}$ and $6 \mathrm{c}$ were also studied at $\mathrm{pH} 6.8$ of the phosphate buffer solution. In this study, applied potential in the controlled potential electrolysis was varied in the range of $0.27-0.75 \mathrm{~V}$ (vs. $\mathrm{Ag} / \mathrm{AgCl}$ ). Potentials lower than $0.27 \mathrm{~V}$ (vs. $\mathrm{Ag} / \mathrm{AgCl})$ were not studied because at potentials lower than $0.27 \mathrm{~V}$, $1 \mathbf{a}$ or $\mathbf{1 b}$ could not be oxidized to the corresponding $o$-benzoquinone (Figure 1, curves $b$ and $c$ ). According to the results obtained (Table 2 ), the yields are high and constant at the potential range of $0.35-0.75 \mathrm{~V}$. Thus a potential of 0.40 $\mathrm{V}(v s . \mathrm{Ag} / \mathrm{AgCl})$ was applied to the working electrodes during the controlled potential electrolysis.

Table 2. Yield of product $6 a$ and $6 \mathrm{c}$ at different applied potential

\begin{tabular}{lcccccccc}
\hline \multicolumn{2}{l}{ Applied potential / V } & 0.27 & 0.35 & 0.40 & 0.45 & 0.55 & 0.70 & 0.75 \\
\hline Yield (\%) & $6 \mathrm{a}$ & 58 & 64 & 75 & 75 & 74 & 75 & 74 \\
Yield (\%) & $6 \mathrm{c}$ & 55 & 66 & 70 & 69 & 70 & 69 & 68 \\
\hline
\end{tabular}




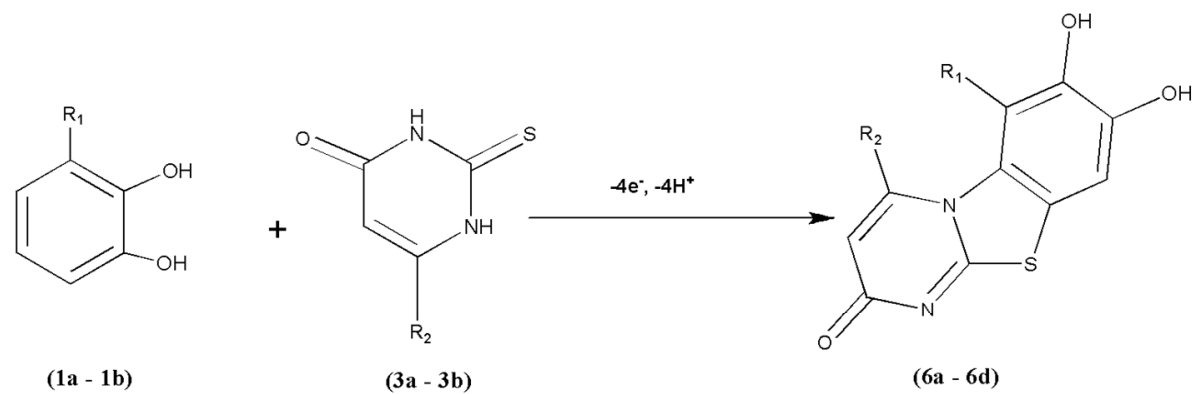

Scheme 1.

\section{Controlled-potential Electrolysis of Catechol (1a) in the Presence of $3 a$ and $3 b$}

Based on the above discussion, the optimized conditions for the anodic oxidation of $\mathbf{1 a}$ in the presence of $\mathbf{3 a}$ and $\mathbf{3 b}$ for the synthesis of $\mathbf{6 a}$ and $\mathbf{6 c}$ are summarized as follow: graphite rod anodes in an undivided cell, phosphate buffer (0.15 $\left.\mathrm{mol} \mathrm{L}^{-1}, \mathrm{pH}=6.8\right) / \mathrm{DMF}(95 / 5)$ solution, and controlled potential at $0.40 \mathrm{~V}$ (vs. $\mathrm{Ag} / \mathrm{AgCl})$.

These conditions were also applied to the anodic oxidation of $\mathbf{1} \mathbf{b}$ in the presence of $\mathbf{3 a}$ and $\mathbf{3} \mathbf{b}$. The obtained results were similar to those of $1 \mathrm{a}$. The mechanism evolves according to Scheme 1.

The controlled-potential coulometry was performed in the previous experimental conditions containing $4.0 \times$ $10^{-3} \mathrm{~mol} \mathrm{~L}^{-1}$ of catechol in the presence of $4.0 \times 10^{-3} \mathrm{~mol} \mathrm{~L}^{-1}$ of 6-methyl-2-thiouracil (Figure 7) and $4.0 \times 10^{-3} \mathrm{~mol} \mathrm{~L}^{-1}$ of 6-propyl-2-thouracil (Figure 8) at the constant anodic potential of $0.40 \mathrm{~V} v$ s. $\mathrm{Ag} / \mathrm{AgCl}$ (volume $80 \mathrm{~mL}$ ). Monitoring of the electrolysis progress was carried out using cyclic voltammetry. It was shown that, proportional to the progress of coulometry, the anodic peak current for catechol oxidation decreases because it reacts with the nucleophiles (Figures 7 and 8). As the coulometric process proceeded, a new and weak cathodic peak $\left(C_{2}\right)$ appeared at the potential of about $0.200 \mathrm{~V}$ that was related to the product. As the electrolysis time increased, the current of this new cathodic peak increased. This is due to an increase of the oxidized quinonic form of compounds $\mathbf{6}(\mathrm{a}-\mathrm{d})$ or intermediates 5 with increasing in electrolysis time. These oxidized quinonic forms are partially adsorbed on the electrode surface and does not involve in the following chemical reaction. Stabilization of cathodic current peak, as the time of electrolysis increased, can be another evidence for the saturation of solution by the electrolytic product. Coulometric process terminated when the charge consumption became about $4 \mathrm{e}^{-}$ per molecule of 1 a (Figures 7 and 8 ).
Since the quinon form of products $\mathbf{6}(\mathbf{a}-\mathbf{d})$ and the intermediates $\mathbf{4}(\mathrm{a}-\mathrm{d})$ can be easily reduced to the catechol form, in the undivided cell, such species could probably involve in reduction $\mathrm{p}$ rocesses at the cathode. Thus controlled-potential coulometry experiments were performed in divided cell. The divided cell was a simple $\mathrm{H}$-cell with

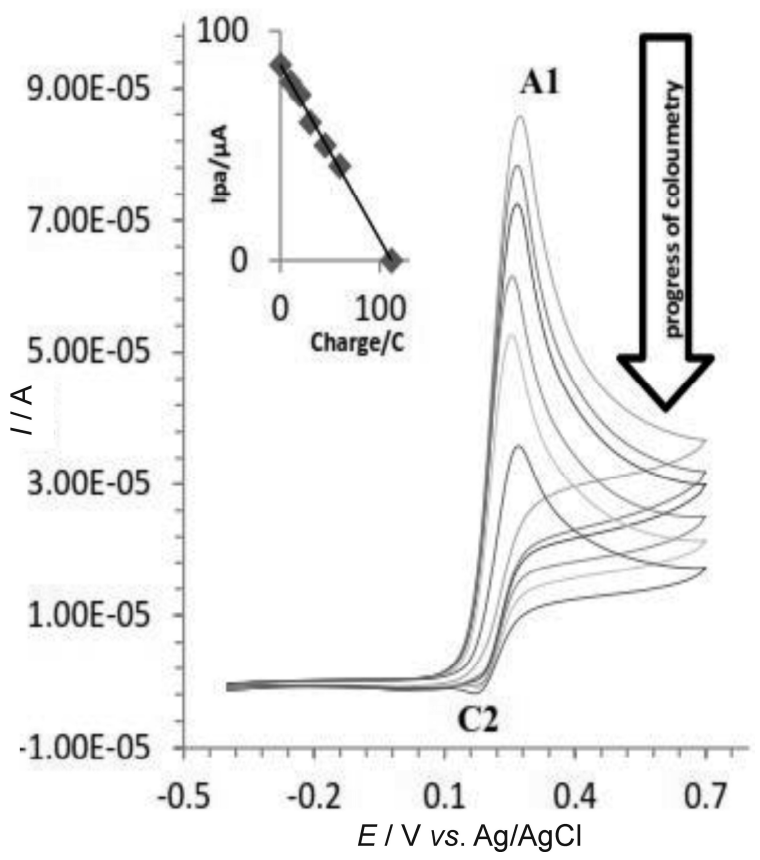

Figure 7. Cyclic voltammograms of $4.0 \times 10^{-3} \mathrm{~mol} \mathrm{~L}^{-1}$ of $1 \mathrm{a}$ in the presence of $4.0 \times 10^{-3} \mathrm{~mol} \mathrm{~L}^{-1}$ of $3 \mathrm{~b}$ in optimal conditions, at a glassy carbon electrode ( $2 \mathrm{~mm}$ diameter) during controlled-potential coulometry at $0.40 \mathrm{~V}$ versus 3 $\mathrm{mol} \mathrm{L}^{-1}$ of $\mathrm{Ag} / \mathrm{AgCl}$ reference electrode. Scan rate of $50 \mathrm{mV}$ $\mathrm{s}^{-1}$ under experimental conditions, room temperature. 
<smiles>[R]c1cccc(O)c1O</smiles>

(1a - 1b)<smiles>[R]c1cc(=O)[nH]c(=S)[nH]1</smiles>

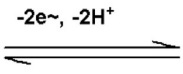<smiles>[R]C1=CC=CC(=O)C1=O</smiles>

$(2 a-2 b)$<smiles>[R]c1cc(=O)nc(S)[nH]1</smiles>

(3a-3b)<smiles>[R]c1cc(=O)nc(S)[nH]1</smiles>

$(3 \mathbf{a}-3 \mathbf{b})$<smiles>[R]C1=CC(CC)=CC(=O)C1CCCCC</smiles>

(2a-2b)<smiles>[R]c1cc(=O)nc(Sc2cc([R])c(O)c(O)c2)[nH]1</smiles>

$(4 a-4 d)$<smiles>[R]c1cc(=O)nc(Sc2cc([R])c(O)c(O)c2)[nH]1</smiles>

$(4 a-4 d)$

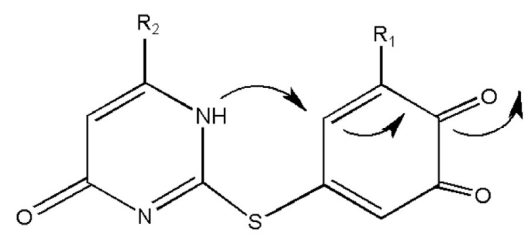

$(5 a-5 d)$

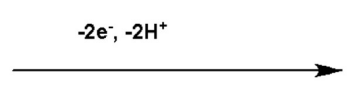<smiles>[R]C1=CC(Sc2nc(=O)cc([R])[nH]2)=CC(=O)C1=O</smiles>

$(5 \mathrm{a}-5 \mathrm{~d})$<smiles></smiles>

(6a- 6d)

Scheme 2 .

same electrodes as undivided cell with a fine glass frit sep arator. The anolyte was the reaction mixture with composition same as that was used in previous experiment (undivided cell). The cathodic compartment was filled with phosphate buffer $\left(0.15 \mathrm{~mol} \mathrm{~L}^{-1}, \mathrm{pH}=6.8\right)$ solution. The obtained results were same as those obtained in the coulometric experiments in the undivided cell and revealed charge consumption about $4 \mathrm{e}^{-}$per molecule of $1 \mathrm{a}$. These results confirm that the quinon form of the product and/or intermediates could not involve in reduction processes at the cathode in an undivided cell. This is due to this fact that the chemical reactions are so fast and consume the intermediates immediately. Thus a simple undivided cell can be used in this study with satisfactory performance. 


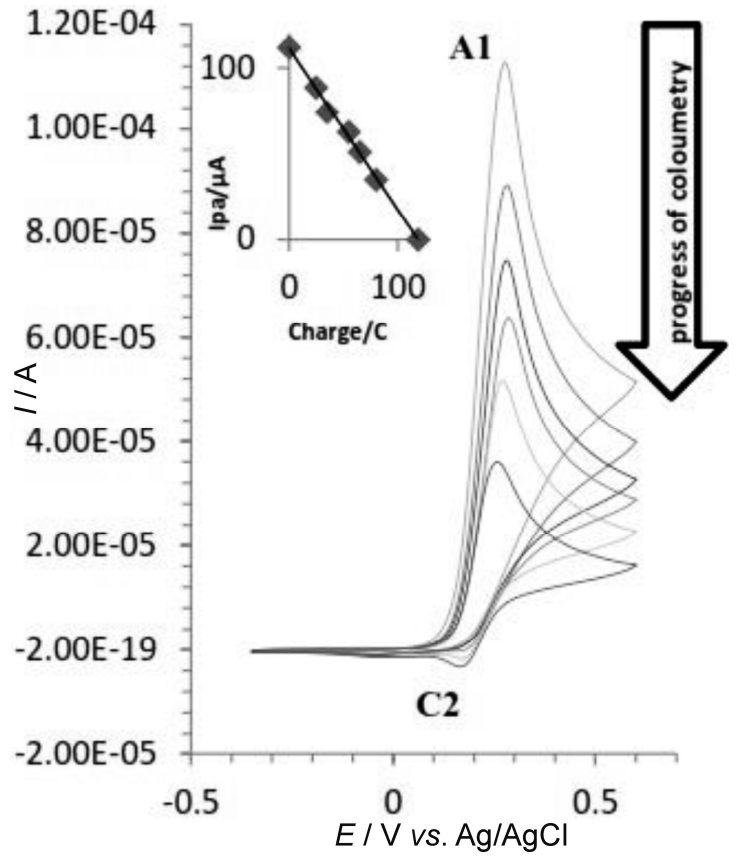

Figure 8. Cyclic voltammograms of $4.0 \times 10^{-3} \mathrm{~mol} \mathrm{~L}^{-1}$ of $1 \mathrm{a}$ in the presence of $4.0 \times 10^{-3} \mathrm{~mol} \mathrm{~L}^{-1}$ of 3 a under experimental conditions, at a glassy carbon electrode ( $2 \mathrm{~mm}$ diameter) during controlled-potential coulometry at $0.40 \mathrm{~V}$ versus 3

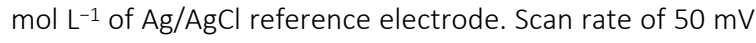
$\mathrm{s}^{-1}$, room temperature.

\section{Reaction Mechanism}

According to our results (Scheme 2), it is clear that the 1,4Michael addition reaction of $\mathrm{SH}$ group $3(\mathrm{a}, \mathrm{b})$ to $o$-quinone $\mathbf{2}(\mathbf{a}, \mathbf{b})$ is much faster than other secondary reactions, leading presumably to the intermediate $4(a-d) .^{22-26}$ The oxidation of this compound $\mathbf{4}(a-d)$ is easier than oxidation of the parent starting molecule $\mathbf{1}(\mathbf{a}, \mathbf{b})$ by virtue of the presence of an electron-donating group, and $\mathbf{5}(\mathbf{a}-\mathbf{d})$ is formed. On the other hand, the NH nucleophile attacks quickly, in a second 1,4-Michael addition, and the product $6(a-d)$ is formed. The presence of a methyl group in $\mathbf{2} \mathbf{b}$, with an electron-donating character at the $\mathrm{C}-3$ position allows two attack possibilities by the $\mathrm{SH}$ group of $\mathbf{3}(\mathbf{a}, \mathbf{b})$ (regioselectivity), to yield two type of products. However, according to the thin layer chromatography (TLC) results obtained and the last studies, ${ }^{22-24}$ we suggest that 3 -methyl-o-quinone (2b) is attacked in the $\mathrm{C}-5$ position by the $\mathrm{SH}$ group $\mathbf{3}(\mathbf{a}, \mathbf{b})$, leading to the formation of the products ( $6 \mathbf{b}$ and $\mathbf{6 d}$ ).

\section{CONCLUSION}

We showed that the electro-synthesis of benzothiazole derivatives can be accomplished by electrochemical oxidation of catechol to o-quinone in aqueous media and subsequent
1,4-Michael addition of $o$-quinone with 6-propyl-2-thiouracil or 6-methyl-2-thiouracil as nucleophiles to $\mathbf{2}(\mathbf{a}, \mathbf{b})$. In this method, the products were prepared in a good yield and purity. An ECEC mechanism was suggested for these products.

Acknowledgment. The authors would like to thank the Shahrood University Research Council for the financial supports of this work.

\section{REFERENCES}

[1] N. Schweigert, A. J. B. Zehnder, R. I. L. Eggen, Environ. Microbiol. 2001, 3, 81.

[2] R. N. Adams, M. D. Hawley, S. W. Feldberg, J. Phys. Chem. 1967, 71, 851.

[3] A. W. Sternson, R. McCreery, B. Feinberg, R. N. Adams, J. Electroanal. Chem. Interfacial Electrochem. 1973, 46, 313.

[4] C. C. Zeng, F. J. Liu, D. W. Ping, L. M. Hu, Y. L. Cai, R. G. Zhong, Tetrahedron 2009, 65, 4505.

[5] D. Nematollahi, H. Goodarzi, J. Electroanal. Chem. 2001, 510, 108.

[6] D. Nematollahi, H. Shayani-jam, J. Org. Chem. 2008, 73, 3428.

[7] M. Rafiee, D. Nematollahi, J. Electroanal. Chem. 2009, 626, 36.

[8] D. Nematollahi, A. Amani, Chem. pharm. Bull. 2008, 56, 513.

[9] M. Wrona, B. Czochralska, D. Shugar, J. Electroanal. Chem. 1976, 68, 355.

[10] J. Carbon, H. David, M. H. Studier, Science 1968, 161, 1146.

[11] M. N. Lippsett, J. Biol. Chem. 1965, 240, 3975.

[12] J. A. Nelson, J. W. Carpenter, M. L. Rose, D. Adamson, J. Cancer Res. 1975, 35, 2872.

[13] S. Shigeta, S. Mori, T. Kira, K. Takahashi, E. Kodama, K. Konno, T. Nagata, H. Kato, T. Wal, N. Koike, M. Saneyoshi, Antivirial Chem. Chemother. 2002, 10, 195.

[14] A. R. Fakhari, D. Nematollahi, M. Shamsipur, S. Makarem, Seyed S. Hosseini Davarani, A. Alizadeh, H. R. Khavasi, Tetrahedron 2007, 63, 3894.

[15] D. Nematollahi, D. Habibi, M. Rahmati, M. Rafiee, J. Org. Chem. 2004, 69, 2637.

[16] A. J. Bard and L. R. Faulkner, Electrochemical Methods, Fundamentals and Applications, 2nd ed., JOHN WILEY \& SONS, New York, 2001, pp. 471-529.

[17] D. Nematollahi and E. Tammari, J. Org. Chem. 2005, 70, 7769 .

[18] D. Nematollahi and Z. Forooghi, Tetrahedron 2002, $58,4949$.

[19] D. I. Stum and S. N. Suslov, Biofizika 1979, 21, 40. 
[20] M. D. Rayn, A.Yueh, C. Wen-Yu, J. Electrochem. Soc. 1980, 127, 1489.

[21] D. Nematollahi, M. Rafiee, A. Samadi-Maybodi, Electrochim. Acta. 2004, 49, 2495.

[22] M. Shamsipur, S. S. H. Davarani, M. Nasiri-Aghdam, D. Nematollahi, Electrochim. Acta. 2006, 51, 3327.

[23] L. Fotouhi, S. T. Kiani, D. Nematollahi, M. M. Heravi,
Int. J. Chem. Kinet. 2007, 39, 340.

[24] F. J. Liu, C. C. Zeng, D. W. Ping, Y. L. Cai, and R. G. Zhong, Chin. J. Chem. 2008, 26, 165.

[25] L. Fotouhi, D. Nematollahi, M. M. Heravia, E. Tammarib, Tetrahedron Lett. 2006, 47, 1713.

[26] L. Fotouhi, R. Hekmatshoar, M. M. Heravi, S. Sadjadi, V. Rasmi, Tetrahedron Lett. 2008, 49, 6628. 